KONSTRUKTIVISME, Vol. 7, No. 2, Juli 2015

p-ISSN: 1979-9438, e-ISSN: 2445-2355

FKIP Universitas Islam Balitar, Blitar

Web: konstruktivisme.unisbablitar.ejournal.web.id

\title{
EDUCATION INNOVATION EFFORTS IN IMPROVING TEACHER COMPETENCY IN TULUNGAGUNG, EAST JAVA
}

\author{
Suyitno \\ STIE Indonesia Malang \\ Email:drsuyitno@yahoo.co.id
}

\begin{abstract}
This study focuses on how education innovation efforts in teacher competency improvement was done through teacher peadagogic, personal, social, and professional competencies empowerment. This research is a field research using a qualitative approach conducted in Tulungagung, East Java dated January to June 2013. Result of this research was that the Education Department of Tulungagung District has made education innovation in serious efforts to improve teachers' competence, including: (1) Educational seminars, (2) Teacher training, (3) Intensive teachers professional development, (4) Teachership Workshop, (5) Subject teacher group discussion strengthenment, (6) Learning design and approach training, (7) Classroom Action Research Training, and (8) Intensive supervision, such as empowerment of teacher peadagogic, personal, social, and professional competencies.
\end{abstract}

Key-words: teacher competencies; peadagogic, personal, social.

\begin{abstract}
Abstrak
Penelitian ini membahas mengenai bagaimana upaya pelaksanaan inovasi pengembangan kompetensi guru melalui pengembangan kompetensi pedagogik, personal, sosial dan profesional. Penelitian ini ialah penelitian lapangan menggunakan pendekatan kualitatif dilaksanakan do Tulungagung, Jawa Timur pada Januari-Juni 2013. Hasil penelitian ialah Depdiknas Kabupaten Tulungagung telah melaksanakan inovasi pendidikan secara serius untuk meningkatkan kompetensi guru, malalui: (1) seminar pendidikan, (2) pelatihan guru, (3) pengembangan profesionalisme guru secara intensif, (4) workshop untuk guru, (5) musyawarah guru bidang mata pelajaran (MGMP), (6) pelatihan desain and pendekatan pembelajaran, (7) pelatihan penelitian tindakan kelas, (8) supervisi intensif, seperti: penguatan kompetensi kedagogik, personal, sosial, dan profesional.
\end{abstract}

Kata-Kunci: kompetensi guru, pedagogik, personal, sosial.

A teacher carries a big responsibility in her classroom. One reason is that all students depend on her. Everything the teacher says will have an impact on the students. If the teacher feels joy of feels anger, it will be 
Competency in Tulungagung, East Java, Konstruktivisme, 7(2): 76-84.

spread among children Because The attitudes of the teacher gets contagious. (Http://www.Csun.edu / meq75037/paper1.html). In a society, from the most backward to the most advanced, the teacher plays an important role as, almost without exception, the builders of prospective society members (Popham, WJ \& Baker, EL 2005).

Lexically teacher is defined as "people whose jobs or occupation is teaching." In a simple term, teacher is the one who gives knowledge to students (Djamaroh, 2008). Meanwhile, the Indonesia Republic Law No. 20, 2003 concerning National Education system confirms that: educators are professionals who are in charge of planning and implementing the learning process, assessing learning outcomes, coaching, training, and conducting research as well as community service, particularly for educators at the higher education. Darajat (1998) says that teachers are professional educators, because implicitly they have volunteered themselves to accept and bear parts of their educational responsibilities mandated by and to the parents' shoulders (Darajat, 1998).

Subroto (1983) also provides definition that educators are adult people who are responsible to give helps to learners in both the learners' bodies and soul in order that they can reach their maturity, can be independent and fulfill their maturity, can be able to stand alone for doing their duties as the Khalifa of Allah, the Almighty God, can be capable as social and independent human beings.

Teachers' roles and responsibilities in education is very hard. Moreover, those the context of Islamic education--all aspects in the Islamic education are bonded to values (value bond), which view teachers not only on the knowledge or material mastery, but also on the moral and spiritual investments investments aspired to be transformed towards the establishment of the Islamic personality; teachers are oblighted to guide, train, and habituate learners to behave well. Therefore, their existance is not only for teaching, but also practicing that of being taught and Islamic education values (Tholkhah \& Barizi, 2004). .

Teachers are people who are very influential in the teaching-learning process. Therefore, teachers should really bring their students to the objectives to be achieved. Teachers must be able to influence their students. Teachers must be visionary and authoritative. Authoritative teachers are those having sincerity, power, and something that can give impression and influence (Wijaya, et al, 1992).

Any person who will carry out the tasks as teachers should have a personality. Besides having personality that suits to the teachings of Islam, religion teachers are more required to have a teacher personality. A teacher is one who should be loved and respected by her students. Her performance in teaching should be convincing and her behavior will be imitated and followed by her students. The teacher is a figure to be emulated and imitated. In carrying out her duties as an educator, she also wants and is willing to do and solve her problems, especially issues that are directly related to the learning process (Darojat, 2001).

According to Fajar (1988), the the tasks of teachers in the future are very hard. It is due to they have to perform tasks of teaching, educating, and guiding their students for the future. In the perspective of Islamic education, the existence, role, and function of teachers are undenial 
nececities. There is no education without the "presence" of teachers. Teachers are determinants of the direction and learning system including the curriculum, facilities, forms and patterns, and efforts to help how students learn, propperly and correctly in order to access knowledge and values of life. A teacher is a "guru" who acts as a guid to towards the better future of students (Tholkhah \& Barizi, 2004). More than the stated above, Dr. Hossein Nasr, Dr. Baloch, Dr. Aroosi and Dr. Badawi also confirm that the central axis of any educational system is teaching (Husain \& Asharaf, 1994).

Considering the above discussion, it is important for teachers to be competent. Efforts to improve their competencies can be advised to conduct. This research was conducted in Tulungagung, East Java, Indonesia. The focus of this study is to research how education innovation in the empowerment of teacher's peadagogic, social, personal, and profesional competencies. This focus is elaborated into: 1. how education innovation in the empowerment of peadagogic competency; 2. how education innovation in the empowerment of social competency, 3 . how education innovation in the empowerment of sosial competency, and 4. how education innovation in the empowerment of professional competency.

Ahmad and Setyaningsih (2012) have researched about "Teacher Professionalism: A Study on Teachers' Professional and Pedagogic Competencies at Junior, Senior, and Vocational High Schools in Banyumas Regency, Central Java, Indonesia". This paper discusses teachers' professionalism. These teachers' competencies are summarized in four competencies, namely professional competency, pedagogic competency, personal comperencies, and social competensies. This study focused on both teachers' professional and pedagogic sompetencies. This study was carried out to research teachers of Junior, Senior, and Vocational High Schools in Banyumas Regency, Central Java, Indonesia.

Setyarahajoe and Irtanto (2013) have researched similar matter entitled "The Competency of Teachers as Human Resourses at Senior High School, in Kediri, East Java, Indonesia". The result of this research shows that the rate of teachers' competencies has satisfactorily in line with standard categories, especially the pedagogic, personal, professional, and social competencies. Of the four competencies stated previously, the weakness existed especially in professional competency that concerns an indicator of scientific writing.

According to Law No 14, 2005 about Teachers and Lecturers, Article 10 paragraph (1), teacher competency includes pedagogical competency, personal competency, social competency, and professional competency that is acquired through professional education. Pedagogical competency is "the ability of learners to manage learning". This competency can be seen from the ability to plan teaching and learning program, the ability to execute the interaction or manage the learning process, and the ability to make an assessment. Teachers' personal competency as educators is their main task in teaching. They are to have good personal characteristics highly influencing the success of people development. Steady personality of the teacher will 
well exemplify learners and community.Therefore, teachers will perform as a figure necessarily followed in advice, words, and commands. Teachers' personality is an important factors for the success of students learning.

Professional competetency is "the ability to master the subject matter broadly and deeply". Professional competencies include expertise in their fields of expertise or mastery of the materials to be taught along with the method, a sense of responsibility and sense of duty to the other teacher colleagues. Whereas, Social competency is "the ability of teachers to communicate and interact effectively and efficiently with students, fellow teachers, parents/guardians of students, and the surrounding community". In this social competency includes skills in social interaction and social responsibilities.

In order to be able to teach effectively, teachers must be able to provide more learning opportunities for students both in the quality and quantity. These can be done by involving students actively in learning. Teachers must be able to show seriousness in teaching so that they can encourage students interest and motivation to learn. To increase the quality of teaching, teachers are advised to professionally develop teaching program planning, deliver instruction in terms of teaching and learning interactions by using the arts of teaching that are satisfactory, full of confidence and high spirit of teaching. They have then to conduct process and result learning evaluation. These will show a part of professional teacher attitude needed in the globalization era. Teachers are to make efforts that what they deliver to students are acceptable and applicable to learners or students.

According to Subroto (1983), factors attached to teachers affecting the teaching and learning programs are personality, material mastery, classroom management, ways of teacher talk, ways of creating classroom situation, concerns for individual principles, openness, collaboration, responsiveness to innovation, willingness and ability to carry out learning experiments. That teachers have the ability to manage learning well, teachers need to have professional skills to meet the 10 competencies of teachers, namely: 1 . Mastering the materials, 2 . Managing the teaching and learning programs, 3. Managing the class, 4. Using media or source, 5. Mastering the foundations of education, 6. Managing the teaching and learning interactions, 7. Assessing students' achievement for the benefit of lessons, 8. Knowing the functions of guidance and counseling services in schools, 9. Understanding the principles of learning, 10. Interpreting the results of educational research for teaching purposes (Subroto, 1983).

\section{METHODS}

This research is a descriptive-qualitative that data collected and expressed data in the form of words and images, words arranged in sentences, such as those the result of interviews between researchers and informants. The presence of the researchers becomes the measure of success or understanding of several cases. The researchers acted asn the main instruments in collecting data. In the qualitative research, the researchers themselves or with the help of other people mas the main instruments of collecting data. These are done by visiting respondents in Tulungagung. This research used purposive sampling, implemented using 
the chimney technique. Data were first collected broadly, then were narrowed and sharpenned on the basis of the research focuses.

This research was conducted in Tulungagung. The sampling areas were of three sub-districts including Township, Kauman and Kedungwaru. This research was done within 4 months beginning from January to June 2013. The sources of data were subjects from where data were obtained". The sources of data were identified into 3 covering informant, document, and place of evidence. In qualitative research data sources are devided by two, which are primary and secondary data. Those obtained directly from the main subjects who are Education Department officials in Tulungagung, Supervisors, and teachers are called primary data and those obtained from other parties are called secondary data, roles and functions of these two data are mutually complementary and supportive.

Techniques of data collection in this research include: (a) in-depth interviews, (b) participant observation, and (c) documentation. Techniques of data analysis is the effort made by working with data, organizing data, sorting them into units that can be managed, synthesized, searched and found what's important and what was learned to be decided for what can be told to others. At this stage the data analysis was done and utilized in such a way to successfully conclude the truths that can be used to answer the questions or issues raised in the study. The methods used to manage qualitative data was by using an inductive method. Inductive method is a set of specific facts, concrete events that is drawn for generalizations that have common properties. This line of thought was used to obtain an opinion consisting of several special opinions. By connecting these opinions, the researchers made generalization.

Validity of the data in this study was determined by using the criteria of credibility (degree of confidence). Credibility of the data is intended to prove that what was compiled in accordance with the reality that exists in the study. To establish the validity of the data, the researchers used inspection technique as follows:

First, extension of research participation, this allowed an increase in the degree of confidence in the data collected. With the extension of participation, the researchers can examine the inaccuracy information introduced by distortion and can build confidence in the subject. So participation is not only done in a short time, but it requires an extension of the participation of researchers on the study background.

Second, perseverance observations, this is meant that the researchers find the characteristics and elements in the situation which is very relevant to the issue that is being searched and then concentrate on such matters in detail.

Third, triangulation, is a technique that utilizes data checking with something else out that data for the purpose of comparison to the data. The technique used is a significant source of triangulation to compare and check back a degree of confidence that the information gained through time and different tools to the path: (1) Comparing the observed data with the interview data, (2) Comparing what people say in public with what he says personally, (3) Comparing state and perspective of someone with different 
opinions and views of the Principal, Teachers, Students, Guardians, and Chairman of the Board of Education, and (4) Comparing what people are saying about the research situation with what he said all time.

\section{FINDING AND DISCUSSION}

Education Department of Tulungagung District, East Java has conducted education innovation by making various efforts in improving teachers' competency seriously. The efforts included: 1. Educational seminar, 2. Teacher training, 3. Sistematic intensive professional teacher development, 3. Teachership workshop, 4. Subject teacher group discussion strengthenment, 5. Learning design and approach training, 6 . Classroom Action Research. Results of the research shows that education innovation in the empowerment od teacher competencies has been done and can be explained as follow:

\section{Pedagogical Competency}

\section{a. Teaching Plan Competency}

Efforts made to empower teacher competency in this area were done by directing and enabling teachers to have the ability of (1) describing objectives, (2) selecting materials, (3) organizing materials, (4) determining learning methods and strategies, (5) determining learning sources, media, and tools, (6) designing assessment and evaluation tools, (7) determining assessment and evaluation technique, and (8) allocating time.

\section{b. Learning and Teaching Process Competency}

Improved Learning and Teaching Process Competency Competency were (1) openning lesson, (2) delivering materials, (3) using media and method, (4) using teaching media, (5) using communicative language, (6) motivating students, (7) organizing activities, (8) interacting with students communicatively, (9) concluding lessons, (10) providing feedback, (11) conducting assessment and evaluation, and (12) using time effectively.

\section{c. Learning and Teaching Assessment and Evaluation Competency}

The teacher empowerment in terms of this compertency turned out to directed to the ability of: (1) choosing questions based on the level of difficulty, (2) selecting questions based on the level of differentiation, (3) repairing the problem is not valid, (4) checking the answer, (5) classifying the results of the assessment, (6) processing and analyzing assessment results, (7) making interpretation of the trend assessment results, determining the correlation problem based on the assessment results, (9) assessing to identify the level of variation in the results, (10) infering from the results of the assessment clearly and logically, (11) arranging followup program assessment results, (12) classifying students, (13) identifying the need for follow-up assessment results, (14 ) carrying out follow-up, (15) evaluating the results of follow-up, and (16) analyzing the results of 
evaluation.

\section{Personal Competency}

The Department of Education, Tulungagung District also conducted optimum teacher personal competency development. Improvement efforts undertaken included personal skills of teachers that are regarding the following: (1) the appearance of a positive attitude towards the overall duties as a teacher, and the overall situation of education and its elements, (2) understanding, appreciation and performance of values. The values should be adopted by teachers, (3) personality, values, attitudes displayed in a bid to establish itself as role models and examples for the students.

\section{Professional Competency}

Efforts made by the Department of Education of Tulungagung District to increase teachers' professional competency included (1) following the development of science and information technology that supports teachers profession through scholarly activities, (2) translating textbooks/scientific papers, (3) developing learning model, (4) writing a paper, (5) writing / composing handbook lessons , (6) writing textbooks, (7) writing module, (8) writing scientific papers, (9) conducting scientific research (action research), (10) finding the appropriate technology, (11) making props/media, (12) creating works of art, (13) accrediting training, (14) following educational qualifications, and (15) following the curriculum development activities. Moreover, competency development also concerned understand insights including (1) understanding the vision and mission, (2) understand-ing the relation between education and teaching, (3) understanding the concept of primary and secondary education, (4) understanding the function of the school, (5) identifying the common problems of education in terms of processes and learning outcomes , (6) establishing a system that shows the linkage of education and out of school. Besides those efforts, mastery of academic study also done. This included (1) understanding the structure of knowledge, (2) mastering the material substance, (3) controlling substance authority in accordance with the type of services learner needed. According above description, the professional competency of teachers has been reflected in the indicators of (1) the ability to master the material lesson, (2) the ability of research and preparation of scientific papers, (3) the ability of professional development, and (4) knowledge and understanding of the educational foundation.

\section{Social Competency}

Education Department Head of Tulungagung District always gived teachers motivation and adevises through meetings and teachers ceremonial teachership avtivities in Tulungagung District, East Java, Indonesia. He always said that effective teachers are those who are able to bring forwards their students to successfully achieve the teaching objectives and learning outcomes. Teaching in the classrooms has become the manifest-ation of interaction for effective communication. The teachers ability to communicate and interact effectively and efficiently with students, 
Competency in Tulungagung, East Java, Konstruktivisme, 7(2): 76-84.

fellow teachers, parents/guardians of students, and the surrounding communities have been well carried out by the teachers in Tulungagung as a result of teachers competency development initiatives and empowerment.

\section{RESEARCH IMPLICATION}

The times are changing in the present era. This messages the teachers, especially, to anticipate future changes in proactively, dynamically, and creatively by preparing them-selves to be self-potential beings as having superior quality and competitive compertency. Therefore, teachers as educators of future generations should have the following capacities:

a. In terms of qualifications: teachers need to have academic eligibility which is not only evidenced by a degree and a diploma, but also is supported by superior qualities.

b. In terms of personality: the teachers need to have a high personality, which is adorned with noble morality in all his/her behavior.

c. In terms of learning: Teachers need to understand the theory and practice of education science and curriculum. They have to be able to design a good learning program, be able to implement learning programs with effective learning art, and be capable in evaluating learning potential. Moreover, the main point is being capable of delivering a successful learners in learning and developing themselves to be mature students.

d. From the social point of view: Teachers as educators need to have social sensitivity in the face of social phenomena around them, because teachers as the elements of society that have different resource quality compared with the other elements of society.

e. In terms of religious matters, teachers need to have a high religious commitment, which manifested as a smart and creative in life.

f. In terms of psychological, teachers need to have the ability to know the mental development of children, both aspects of intellectual, emotional, and spiritual. Development in proportion to the third aspect of that intelligence needs teachers attention maximally.

g. In terms of strategy: Teachers need to enrich themselves with a variety of methods, approaches, and techniques of learning which has more reliability in delivering learners learning achieve goals.

\section{REFERENCES}

Ahmad and Setyaningsih. 2012. Teacher Professionalism: A Study on Teachers' Professional and Pedagogic Competence at Junior, Senior, and Vocational High Schools in Banyumas Regency, Central Java, Indonesia.In Sosiohumanika, Jurnal Pendidikan sain sosial dan Kemanusiaan, Vol.5, No.1. Tahun 2012

Darajat, Z. 1998. Ilmu Pendidikan Islam. Jakarta: Penerbit Bumi Angkasa.

Darojat , Z. 2001. Metodologi Pengajaran Agama Islam. Jakarta: Bumi Aksara.

Djamaroh, S. B. 2008. Guru dan Anak didik Dalam Interaksi Edukativ. Jakarta: Rineka Cipta. 
Fadjar, M. 1998. Visi Pembaharuan Pendidikan Islam. Jakarta: LP3NI.

Husain, S.S. \& Asharaf, S.A. 1994. Menyongsong Keruntuhan Pendidikan Islam , Terj. Rahmani Astuti. Bandung: CV. Gema Risalah Press.

Popham, W. J. \& Baker, E.L. 2005. Tehnik Mengajar Secara Sistematis. Jakarta: Rineka Cipta.

Ratna Setyarahajoe and Irtanto. 2013. The Competence of Teacher as Human Resourses at Senior High School of Kediri City East Java Province Indonesia, in Academic Research International, Vol. 4 No. 1 January 2013.

Subroto, S. 1983. Beberapa Aspek Dasar Kependidikan. Jakarta: Bina Aksara.

Subroto, S. 1997. Proses Belajar Mengajar di Sekolah. Jakarta: Rineka Cipta.

Tholkhah, I. \& Barizi, A. 2004. Membuka Jendela Pendidikan- Mengurai Akar Tradisi dan Integrasi Keilmuan Pendidikan Islam. Jakarta: Penerbit Raja Grafindo.

UU nomor 20 tahun 2003 tentang Sistem pendidikan Nasional. Bandung: Citra Umbara.

Wijaya, C. \& Djadjuri , D. Rusyan, A.T. 1992. Upaya Pembaharuan Dalam Pendidikan Dan Pengajaran. Bandung: PT Remaja Rosdakarya 